\title{
Performance of Conventional Cytology and Colposcopy for the Diagnosis of Cervical Squamous and Glandular Neoplasias
}

\section{Desempenho da citologia convencional e da colposcopia para o diagnóstico de neoplasias cervicais escamosas e glandulares}

\author{
Giselle Fachetti-Machado ${ }^{1}$ Rosane Ribeiro Figueiredo-Alves ${ }^{1} \quad$ Marise Amaral Rebouças Moreira ${ }^{1}$ \\ ${ }^{1}$ Health Sciences Postgraduate Program, Universidade Federal de \\ Goiás, Goiânia, GO, Brazil \\ Address for correspondence Giselle Fachetti-Machado, MD, MSc, \\ Universidade Federal de Goiás, Av. T4, esq. com T13, 1478, Salas 91B e \\ 92B, Setor Bueno, Goiânia, GO, 74230-030, Brazil \\ Rev Bras Ginecol Obstet 2018;40:410-416. \\ (e-mail: gfachettimachado@uol.com.br).
}

\author{
Abstract \\ Keywords \\ - uterine cervical \\ neoplasms \\ - cervical \\ intraepithelial \\ neoplasia \\ - squamous \\ intraepithelial lesions \\ of the cervix \\ - adenocarcinoma in \\ situ \\ - papanicolaou test \\ - colposcopy \\ - sensitivity and \\ specificity
}

Objective To estimate the cytological and colposcopic performances for the diagnosis of cervical neoplasias.

Methods Cross-sectional retrospective study with data from patients' charts. The participants underwent colposcopy, guided biopsies, and excision when needed. The cytological and colposcopic categorization followed the Bethesda System and the international colposcopic terminologies. The cytology and colposcopy performances were evaluated by sensitivity (SE), specificity (SP), positive predictive value (PPV), and negative predictive value (NPV) analyses with $95 \%$ confidence interval $(95 \% \mathrm{Cl})$.

Results From 1,571 participants, a total of 1,154 (73.4\%) were diagnosed with cervical squamous intraepithelial neoplasia grade 2 or worse (CIN 2+), $114(7.2 \%)$ with adenocarcinoma in situ or worse $\left(\mathrm{AIS}^{+}\right), 615$ (39.2\%) presented atypical squamous cells, cannot exclude high-grade squamous intraepithelial lesion or worse $\left(\mathrm{ASC}-\mathrm{H}^{+}\right.$) cytology, and 934 (59.4\%) presented major or suspicious for invasion colposcopic abnormalities. The SE, SP, PPV, and NPV of ASC- $\mathrm{H}^{+}$for diagnoses of $\mathrm{CIN}^{+}$and $\mathrm{AIS}^{+}$ were, respectively: 44\% (95\% Cl: 41-47) and 72\% (95\% Cl: 67-76), 79\% (95\% Cl: 77-81) and $79 \%$ (95\% Cl: $75-83$ ), 88\% (95\% Cl: 87-90) and 55\% (95\% Cl: 50-60), and 28\% (95\% CI: 26-31) and 88\% (95\% CI: 85-91). The SE, SP, PPV, and NPV of major or suspicious for

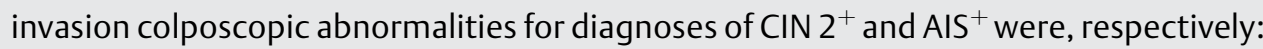
62\% (95\% Cl: $60-65)$ and 86\% (95\% Cl: 83-89), 59\% (95\% Cl: 57-62) and 59\% (95\% Cl: 55-64), 85\% (95\% Cl: 83-87) and 44\% (95\% Cl: 40-49), and 29\% (95\% Cl: 27-32) and 92\% (95\% Cl: 89-94).

Conclusion The SE analyses results of $\mathrm{ASC}^{-} \mathrm{H}^{+}$and major or suspicious for invasion colposcopic abnormalities were higher for diagnoses of glandular neoplasias. These results confirm the role of cytology in identifying women at risk who will have their final diagnoses settled by colposcopy and histology. received

February 3, 2018

accepted

May 17, 2018

published online

July 11,2018
DOI https://doi.org/

10.1055/s-0038-1666995. ISSN 0100-7203.
Copyright $\odot 2018$ by Thieme Revinter

Publicações Ltda, Rio de Janeiro, Brazil
License terms

(c) (i) $\ominus$ (\$) 


\section{Resumo}

\section{Palavras-chave}

- neoplasias do colo do útero

- neoplasia intraepitelial cervical

- lesões intraepiteliais escamosas cervicais

- adenocarcinoma in situ

- exame colpocitológico

- colposcopia

- sensibilidade e especificidade
Objetivo Estimar o desempenho da citologia e colposcopia no diagnóstico das neoplasias cervicais.

Métodos Estudo retrospectivo de corte transversal com dados coletados em prontuários. Foram incluídas participantes que foram submetidas a colposcopia, biópsia e excisão quando necessário. A categorização da citologia e da colposcopia seguiram a terminologia de Bethesda e a classificação colposcópica internacional. Os desempenhos da citologia e colposcopia foram avaliados por análises de sensibilidade (S), especificidade (E), valor preditivo positivo (VPP) e valor preditivo negativo (VPN), com intervalos de confiança de 95\% (IC 95\%).

Resultados Das 1.571 participantes, um total de $1.154(73,4 \%)$ foram diagnosticadas com neoplasia intraepitelial escamosa cervical de grau 2 ou mais grave (NIC $2^{+}$), 114 $(7,2 \%)$ com adenocarcinoma in situ ou mais grave $\left(\mathrm{AIS}^{+}\right), 615(39,2 \%)$ apresentaram células escamosas atípicas de significado indeterminado, quando não se pode excluir lesão intraepitelial de alto grau ou mais grave $\left(\right.$ ASC-H $\left.{ }^{+}\right)$e $934(59,4 \%)$ tiveram achados colposcópicos maiores ou suspeitos de invasão. Os valores de S, E, VPP e VPN das ASC$\mathrm{H}^{+}$para o diagnóstico de $\mathrm{NIC} 2^{+}$e $\mathrm{AIS}^{+}$foram, respectivamente: $44 \%$ (IC 95\%: 41-47) e 72\% (IC 95\%: 67-76), 79\% (IC 95\%: 77-81) e 79\% (IC 95\%: 75-83), 88\% (IC 95\%: 87-90) e 55\% (IC 95\%: 50-60) e 28\% (IC 95\%: 26-31) e 88\% (IC 95\%: 85-91). Os valores de S, E, VPP e VPN dos achados colposcópicos maiores ou suspeitos de invasão para o diagnóstico de NIC $2^{+}$e $\mathrm{AIS}^{+}$foram, respectivamente: 62\% (IC 95\%: 60-65) e $86 \%$ (IC 95\%: 83-89), 59\% (IC 95\%: 57-62) e 59\% (IC 95\%: 55-64), 85\% (IC 95\%: 83-87) e 44\% (IC 95\%: 40-49) e 29\% (IC 95\%: 27-32) e 92\% (IC 95\%: 89-94).

Conclusão Os resultados das análises de $\mathrm{S}$ de $\mathrm{ASC}^{-\mathrm{H}^{+}}$e achados colposcópicos maiores ou suspeitos de invasão foram mais elevados para o diagnóstico das neoplasias glandulares. Esses resultados confirmam o papel da citologia na identificação de mulheres em risco que terão seus diagnósticos definidos por colposcopia e histologia.

\section{Introduction}

Well organized invasive cervical cancer (ICC) screening programs based on cytology, colposcopically-guided biopsies, and treatment of precursor neoplasias have led to an important decrease in the ICC incidence and mortality. However, none of these programs could eradicate cervical cancer in any part of the globe. ${ }^{1}$ In fact, evidences have shown that in the last decades, the incidence of cervical adenocarcinoma (AC) has risen, especially in younger women, denoting the lack of impact of these programs for this particular histological type. ${ }^{2}$

Although the triage of patients at risk for ICC precursor lesions is based on cytological abnormalities, these do not have adequate specificity to indicate treatment to all women with such findings. ${ }^{3}$ Therefore, colposcopically-guided biopsy was added to the system aiming to select which women with abnormal cytology would actually need treatment. ${ }^{4}$

Recently, as expected, a decrease in the prevalence of cervical intraepithelial neoplasias has been observed in developed countries due to high human papillomavirus (HPV) vaccination coverage. ${ }^{5}$ It is possible that in vaccinated populations, the neoplasias that will still be found will show more subtle appearance and smaller sizes. ${ }^{6}$ At the same time, a better diagnostic performance has been reached with the introduction of new screening programs with high sensitiv- ity, which added DNA detection methods to cytology, resulting in a decrease in false-negatives, ${ }^{6}$ and an improvement in cytological detection rates, even for more discrete neoplasias. Nonetheless, knowledge about colposcopy performance is still needed, especially regarding the recognition of subtle neoplasias, ${ }^{6}$ which could be missed since colposcopic criterion has not been updated to the new scenario.

The histopathological diagnosis of specimens obtained using colposcopically-guided biopsy has been traditionally considered the gold standard for cytological and colposcopic analyses. However, this assumption has an intrinsic flaw. ${ }^{4}$ Any mistakes made when choosing the site to take the biopsies, due to a misinterpretation of the colposcopic images, would necessarily lead to a bias, compromising the results of these analyses.

This study estimated cytological and colposcopic performance to predict the final diagnosis of squamous and glandular neoplasias and determine the performance of these diagnostic tests used in clinicians' daily practice, considering that the final diagnosis was based on excisional specimens.

\section{Methods}

This cross-sectional epidemiological study was based on data collected over a period of 24 years, from April 16, 1991 to November 26, 2015, in a private colposcopy health unit in 
Goiânia, GO, Brazil. The project was approved by the Research Ethics Committee of the Hospital das Clínicas of the Universidade Federal de Goiás (CAAE no. 58228016.1.0000.5078).

A total of 11,999 medical records of patients referred to colposcopy were reviewed. Among them, 1,527 participants were selected for having their final diagnoses settled by histopathological analyses of transformation zone excision (TZE) pieces, 7 by analysis of cold knife conization (CKC) pieces, and 37 with invasive cervical neoplasias diagnosed in the initial biopsy fragment. Therefore, the final sample was composed of 1,571 participants.

All the patients without a histopathological analysis of an excisional specimen were excluded from the study, even if they had cytological abnormalities, and regardless of whether they had normal or abnormal histopathology. Exceptions were made only in the cases with stromal invasion observed in the initial biopsy fragment, because once invasion is found, no worst diagnosis is possible, making a subsequent excisional procedure unnecessary in most cases.

The data obtained from patients' charts, colposcopic reports, and computer software Diagnose Pro 6, Ginecologia e Obstetrícia, prontuário eletrônico e captura de imagens. (LPT4 sistemas de informação, Curitiba, Paraná, Brazil) and Zscan 7 Gineco, version 7.4 (Zscan Software, 2001-2016, Goiânia, Goiás, Brazil) image files were coded and kept on a 2013 Excel spreadsheet (Microsoft Corp., Redmond, WA, USA). The cytological, colposcopic, and histopathological data included referral cytology, colposcopic findings, visualization of squamocolumnar junction (SCJ), the histopathological diagnosis of an excision piece or a hysterectomy piece, and the histopathological report of biopsy fragments.

The cytological abnormalities were classified as proposed by the Bethesda terminology, updated in 2014: ${ }^{7}$ atypical squamous cells of undetermined significance (ASC-US), lowgrade squamous intraepithelial lesion (LSIL), atypical squamous cells, cannot exclude high-grade squamous intraepithelial lesion (ASC-H), high-grade squamous intraepithelial lesion (HSIL), squamous cell carcinoma (SCC), atypical glandular cells (AGC), adenocarcinoma in situ (AIS), and adenocarcinoma (AC).

The ASC- $\mathrm{H}^{+}$group had a cut-off point settled in the cytological results of ASC-H or worse, a threshold in which the patients' management changes to immediate referral to colposcopy rather than the mere cytological follow-up. ${ }^{8}$ This group included all patients with cytological abnormalities classified as ASC-H, HSIL, SCC, AIS, and AC.

A single colposcopist performed the exams using at first a 5-fold DFV videocolposcope (D. F. Vasconcellos, Valença, RJ, Brazil) and afterward a Medpej PE 7000 MDL videocolposcope also with five levels of magnification (6x, 10x, 16x, 25x and $40 x$ ). Initially $5 \%$ and $10 \%$ acetic acid solutions were applied followed by the spraying of Schiller's solution, at this point, the needed biopsies were taken with Gaylor-Medina forceps. Endocervical currettages with a Kevorkian curette were performed whenever necessary.

The colposcopic images were reviewed by the examiner and the 2011 International Federation of Cervical Pathology and Colposcopy (IFCPC) ${ }^{9}$ terminology was used to group them as follows: normal, minor findings, major findings, or suspicious for invasion. Minor findings elementary images included: fine mosaic, fine punctuation, and thin acetowhite epithelium with geographic borders. Major findings included: coarse mosaic, coarse punctuation, and dense acetowhite epithelium with sharp border, with or without ridge and inner border sign, and also cuffed crypt openings. The images considered suspicious for invasion included: atypical or fragile vessels, irregular surface, exophytic lesion, necrosis, necrotic ulceration, and gross neoplasm. ${ }^{9}$

Moreover, new colposcopic images similar to those described by Wright et $\mathrm{al}^{10}$ were added to the major findings category. It is necessary to emphasize that these images are not accredited by IFCPC terminology.

The cut-off point of colposcopic images was settled at images worse than minor findings, since taking biopsies from this type of findings is considered needless by many colposcopists. Thus, the colposcopic findings were sorted into two groups: 1) normal and minor findings; 2) major findings and suspicious for invasion findings.

A Wavetronic 5000 Digital Hf Surgical Unit (Loktal Medical Electronics Ind. Com. Ltda, São Paulo, SP, Brazil) was employed to perform TZE under colposcopic guidance and local anestesia, using its handswitch pencil and cord with loop electrodes, at $50 \%$ of the coagulation power and the shear power regulated to output 8 . A single-fragment resection was performed unless a large transformation zone was present.

A single examiner performed all histopathological analyses and categorized the findings following the World Health Organization International Tumors Classification ${ }^{11}$ and the Richart Classification for cervical intraepithelial neoplasias. $^{12}$ The final diagnosis was defined as the most severe histopathological diagnosis among specimens of excision or hysterectomy, except when invasion was already found in fragments of initial biopsies.

The data analysis was performed using the Statistical Package for Social Sciences (SPSS) for Windows version 21.0 (IBM Corp., Armonk, NY, USA). Descriptive analyses of the sociodemographic, behavioral, and clinical features as well as cytological abnormalities, colposcopic findings, and histopathological diagnosis were performed.

Diagnostic performance of cytological abnormalities and colposcopic findings to predict the final diagnosis were evaluated by analysis of sensitivity (SE), specificity (SP), positive predictive value (PPV), and negative predictive value (NPV), with the respective 95\% confidence interval $(95 \% \mathrm{CI})$. Values of SE, SP, PPV, and NPV between 0.00 and 0.40 were considered as poor, between 0.40 and 0.60 as low, between 0.60 and 0.80 as moderate, and between 0.80 and 1 as high.

\section{Results}

The sociodemographic and behavioral characteristics of the participants in this survey are shown in - Table 1. The mean age of the participants was 31.7 years and at the first intercourse, it was 18.9 years. A total of 615 (39.6\%) patients out of 1,571 were referred to colposcopy due to cytological findings of atypical squamous cells, cannot exclude highgrade squamous intraepithelial lesion or worse $\left(\right.$ ASC $\left.-\mathrm{H}^{+}\right)$. 
Table 1 Sociodemographic and behavioral profile of 1,571 participants

\begin{tabular}{|c|c|c|}
\hline \multicolumn{3}{|l|}{ Variables } \\
\hline Age & \multicolumn{2}{|l|}{ Years } \\
\hline Range & \multicolumn{2}{|l|}{$15-85$} \\
\hline Mean (sd) & \multicolumn{2}{|c|}{$31.7 \pm 10.8$} \\
\hline Marital status ${ }^{a}$ & $n$ & $\%$ \\
\hline Single & 817 & 52.0 \\
\hline Married & 752 & 47.9 \\
\hline Age at first intercourse ${ }^{b}$ & \multicolumn{2}{|l|}{ Years } \\
\hline Range & \multicolumn{2}{|l|}{$9-47$} \\
\hline Mean (sd) & \multicolumn{2}{|c|}{$18.9 \pm 3.7$} \\
\hline Lifetime sexual partners $^{c}$ & $\bar{n}$ & $\%$ \\
\hline$\leq 2$ & 624 & 39.7 \\
\hline$>2$ & 756 & 48.1 \\
\hline Full-term pregnancy $^{d}$ & $\bar{n}$ & $\%$ \\
\hline$\leq 1$ & 1,107 & 70.5 \\
\hline$>1$ & 453 & 28.8 \\
\hline Tobacco use $\mathrm{e}^{\mathrm{e}}$ & $n$ & $\%$ \\
\hline Past and current smoker & 148 & 9.4 \\
\hline Never smoker & 1,073 & 68.3 \\
\hline
\end{tabular}

Abbreviation: SD, standard deviation. missing data: ${ }^{\mathrm{a}} 2$; ${ }^{\mathrm{b}} 128$; ${ }^{\mathrm{c}} 192$; ${ }^{\mathrm{d}} 11$; e350.

Colposcopic images categorized as major or suspicious for invasion were found in 934 (59.4\%) patients (-Table 2). Concerning the final diagnosis, 1,154 (73.4\%) participants had cervical squamous intraepithelial neoplasia grade 2 or worse $\left(\mathrm{CIN}^{+}\right)$and 114 (7.2\%) had adenocarcinoma in situ or worse $\left(\mathrm{AIS}^{+}\right)$(-Table 2 ).

The SE, SP, PPV, and NPV results of $\mathrm{ASC}^{-} \mathrm{H}^{+}$for the prediction of CIN $2^{+}$were, respectively: $44 \%$ (95\% CI $41-$ 47), 79\% (95\% CI: 77-81), 88\% (95\% CI: 87-90), and 28\% (95\% CI: 26-31). The SE, SP, PPV, and NPV results of ASC-H ${ }^{+}$for the prediction of $\mathrm{AIS}^{+}$were, respectively: $72 \%$ (95\% CI: $67-$ 76), 79\% (95\% CI: 75-83), 55\% (95\% CI: 50-60), and 88\% (95\% CI: 85-91) (-Table 3).

The SE, SP, PPV, and NPV results of major or suspicious for invasion colposcopic findings for the diagnosis of CIN $2^{+}$were, respectively, 62\% (95\% CI: 60-65), 59\% (95\% CI: 57-62), 85\% (95\% CI: 83-87), and 29\% (95\% CI: 27-32), whereas to detect AIS ${ }^{+}$they were, respectively, 86\% (95\% CI: 83-89), 59\% (95\% CI: 55-64), 44\% (95\% CI: 40-49), and 92\% (95\% CI: 89-94) (-Table 4).

\section{Discussion}

In the present study, the performances of cytological abnormalities ASC- $\mathrm{H}^{+}$and colposcopic major or suspicious for invasion findings were evaluated to separately predict the final diagnoses of $\mathrm{CIN}^{+}$and $\mathrm{AIS}^{+}$in a sample of 1,571 participants. The final diagnosis was defined as the most severe report obtained among all biological specimens of
Table 2 Cytological, colposcopic, and final diagnoses in 1,571 participants

\begin{tabular}{|l|l|l|}
\hline Colposcopy referral & $\mathbf{n}$ & $\%$ \\
\hline ASC-US/LSIL & 796 & 50.7 \\
\hline ASC-H/HSIL & 532 & 34.0 \\
\hline AGC & 29 & 1.8 \\
\hline Adenocarcinoma in situ & 22 & 1.4 \\
\hline Squamous cell carcinoma & 16 & 1.0 \\
\hline Adenocarcinoma & 16 & 1.0 \\
\hline Others ${ }^{\text {a }}$ & 153 & 9.7 \\
\hline Colposcopy findings ${ }^{\text {b }}$ & $\mathrm{n}$ & $\%$ \\
\hline Normal & 9 & 0.5 \\
\hline Minor & 618 & 39.3 \\
\hline Major & 908 & 57.8 \\
\hline Suspicious for invasion & 26 & 1.6 \\
\hline Final diagnosis & $\mathrm{n}$ & $\%$ \\
\hline$\leq$ CIN 1 & 303 & 19.3 \\
\hline CIN 2/CIN 3 & 1,124 & 71.6 \\
\hline Microinvasive squamous carcinoma & 13 & 0.8 \\
\hline Squamous carcinoma & 17 & 1.1 \\
\hline Adenocarcinoma in situ & 78 & 5.0 \\
\hline Microinvasive adenocarcinoma & 8 & 0.5 \\
\hline Adenocarcinoma & 28 & 1.8 \\
\hline
\end{tabular}

Abbreviations: AGC, atypical glandular cells; ASC-H, atypical squamous cells, cannot exclude high-grade squamous intraepithelial lesion; ASC-US, atypical squamous cells of undetermined significance; CIN, cervical intraepithelial neoplasia; HSIL, high-grade squamous intraepithelial lesion; LSIL, low-grade squamous intraepithelial lesion. ${ }^{a}$ cervical polip, cervical bleeding, unknown cytological finding, etc. bmissing data: 10 .

patients who underwent excisional procedure, except when invasion was initially found in biopsy fragments.

The SE of ASC- ${ }^{+}$(44\%) to identify squamous neoplasias was low; in contrast, SP (79\%) and PPV (88\%) were moderate and high, respectively. Regarding glandular neoplasias, SE (72\%) and SP (79\%) of ASC- $\mathrm{H}^{+}$were moderate, whereas PPV (55\%) was low. To the best of our knowledge, to date, no studies have simultaneously measured the performance of cytological and colposcopic diagnoses of squamous and glandular neoplasias.

The sensitivity of a test represents its ability to correctly identify unhealthy individuals, while its specificity shows the ability to identify the healthy ones. ${ }^{13}$ Therefore, the low sensitivity found implies that $\mathrm{ASC}-\mathrm{H}^{+}$may not sort out a reasonable number of patients with $\mathrm{CIN} 2^{+}$, since the falsenegative rate was high (56\%). Similarly, the SP of $79 \%$ obtained means that absence of $\mathrm{ASC}-\mathrm{H}^{+}$identifies a high number of patients that do not actually have CIN $2^{+}$.

Moderate SE (72\%) and SP (79\%) of $\mathrm{ASC}-\mathrm{H}^{+}$to identify glandular neoplasias mean that ASC- $\mathrm{H}^{+}$involves lower rates of false-positives (28\%) and false-negatives (21\%). Analyzed individually, SE of cytology for the detection of glandular 
Table 3 Performance of cytological findings of atypical squamous cells, cannot exclude high-grade squamous intraepithelial lesion or worse $\left(\mathrm{ASC}-\mathrm{H}^{+}\right)$to predict final diagnosis of squamous and glandular cervical neoplasias

\begin{tabular}{|c|c|c|c|c|}
\hline $\begin{array}{l}\text { Cytological } \\
\text { findings }\end{array}$ & \multicolumn{2}{|c|}{ Final diagnosis } & \multicolumn{2}{|c|}{$\begin{array}{l}\text { Estimated performance } \\
(\%)(95 \% \mathrm{Cl})\end{array}$} \\
\hline \multirow[t]{2}{*}{$\mathrm{ASC}_{-} \mathrm{H}^{+}$} & \multicolumn{2}{|c|}{$\mathrm{CIN} 2^{+}(n=1,376)$} & & \\
\hline & Positive & Negative & & \\
\hline \multirow[t]{2}{*}{ Positive } & \multirow[t]{2}{*}{474} & \multirow[t]{2}{*}{63} & Sensitivity & $44(41-47)$ \\
\hline & & & Specificity & $79(77-81)$ \\
\hline \multirow[t]{2}{*}{ Negative } & \multirow[t]{2}{*}{603} & \multirow[t]{2}{*}{236} & PPV & $88(87-90)$ \\
\hline & & & NPV & $28(26-31)$ \\
\hline \multirow[t]{2}{*}{$\mathrm{ASC}^{+} \mathrm{H}^{+}$} & \multicolumn{2}{|c|}{$\mathrm{AIS}^{+}(n=408)$} & \multirow{2}{*}{\multicolumn{2}{|c|}{$\begin{array}{l}\text { Estimated performance } \\
(\%)(95 \% \mathrm{Cl})\end{array}$}} \\
\hline & Positive & Negative & & \\
\hline \multirow[t]{2}{*}{ Positive } & \multirow[t]{2}{*}{78} & \multirow[t]{2}{*}{63} & Sensitivity & $72(67-76)$ \\
\hline & & & Specificity & $79(75-83)$ \\
\hline \multirow[t]{2}{*}{ Negative } & \multirow[t]{2}{*}{31} & \multirow[t]{2}{*}{236} & PPV & $55(50-60)$ \\
\hline & & & NPV & $88(85-91)$ \\
\hline
\end{tabular}

Abbreviations: $\mathrm{AlS}^{+}$, adenocarcinoma in situ or worse; ASC-H ${ }^{+}$, atypical squamous cells, cannot exclude high-grade squamous intraepithelial lesion or worse (including ASC-H, HSIL, AIS, SCC, and AC); CIN $2^{+}$, cervical squamous intraepithelial neoplasia grade 2 or worse; $95 \% \mathrm{Cl}$, 95\% confidence interval; NPV, negative predictive value; PPV, positive predictive value.

neoplasias has been reported in a wide range of values, such as $43.1 \%{ }^{14}$ and $91.2 \%{ }^{15}$ Those results contrast with the findings of this study, since most patients with glandular neoplasias were found using $\mathrm{ASC}-\mathrm{H}^{+}(72 \%)$ cytology, and most patients without cytological reports of ASC-H ${ }^{+}$(NPV $88 \%$ ) were truly free of glandular neoplasias. For this reason, when ASC- $\mathrm{H}^{+}$is found, whether squamous neoplasias have already been identified or not, it would be safer to exclude the possibility of coexistent glandular neoplasias.

Sensitivity and SP are inherent properties of a test and do not change. However, the predictive values depend on the prevalence of the disease in the study sample. ${ }^{13}$ Therefore, the PPV will proportionally increase according to the prevalence of the disease in the studied group. In the present study, on one hand, the high prevalence of squamous neoplasias implied a high PPV of ASC- $\mathrm{H}^{+}$for $\mathrm{CIN} 2^{+}$detection, because most participants with ASC- $\mathrm{H}^{+}$actually had CIN $2^{+}$. On the other hand, the low prevalence of glandular neoplasias implied a low PPV of ASC- $\mathrm{H}^{+}$ability to predict AIS $^{+}$. Hence, most positive results of ASC- $\mathrm{H}^{+}$do not correspond to patients with glandular neoplasias, but rather to patients with squamous neoplasias.

Evidences involving the performance of cytological abnormalities for predicting intraepithelial and invasive cervical neoplasias, whether squamous or glandular, were found with SE ranging from 30 to $100 \%$, and SP from 86.8 to 99.3\%. ${ }^{16-29}$ This large divergence may be due to the diversity of cut-off points chosen to consider the tests as positive or negative, as well as to the use of different morphological criteria to interpret cytological smears and classify abnormal
Table 4 Performance of major or suspicious for invasion colposcopic findings to predict final diagnosis of squamous and glandular cervical neoplasias

\begin{tabular}{|c|c|c|c|c|}
\hline $\begin{array}{l}\text { Colposcopic } \\
\text { report }\end{array}$ & \multicolumn{2}{|c|}{ Final diagnosis } & \multicolumn{2}{|c|}{$\begin{array}{l}\text { Estimated performance } \\
\text { (\%) }(95 \% \mathrm{Cl})\end{array}$} \\
\hline \multirow{2}{*}{$\begin{array}{l}\text { Major or } \\
\text { suspicious } \\
\text { for invasion }\end{array}$} & \multicolumn{2}{|c|}{$\operatorname{CIN~} 2^{+}(n=1,447)$} & & \\
\hline & Positive & Negative & & \\
\hline \multirow[t]{2}{*}{ Positive } & \multirow[t]{2}{*}{713} & \multirow[t]{2}{*}{123} & Sensitivity & $62(60-65)$ \\
\hline & & & Specificity & $59(57-62)$ \\
\hline \multirow[t]{2}{*}{ Negative } & \multirow[t]{2}{*}{432} & \multirow[t]{2}{*}{179} & PPV & $85(83-87)$ \\
\hline & & & NPV & $29(27-32)$ \\
\hline \multirow{2}{*}{$\begin{array}{l}\text { Major or } \\
\text { suspicious } \\
\text { for invasion }\end{array}$} & \multicolumn{2}{|c|}{$\mathrm{AIS}^{+}(n=416)$} & \multirow{2}{*}{\multicolumn{2}{|c|}{$\begin{array}{l}\text { Estimated performance } \\
(\%)(95 \% \mathrm{Cl})\end{array}$}} \\
\hline & Positive & Negative & & \\
\hline \multirow[t]{2}{*}{ Positive } & \multirow[t]{2}{*}{98} & \multirow[t]{2}{*}{123} & Sensitivity & $86(83-89)$ \\
\hline & & & Specificity & $59(55-64)$ \\
\hline \multirow[t]{2}{*}{ Negative } & \multirow[t]{2}{*}{16} & \multirow[t]{2}{*}{179} & PPV & $44(40-49)$ \\
\hline & & & NPV & $92(89-94)$ \\
\hline
\end{tabular}

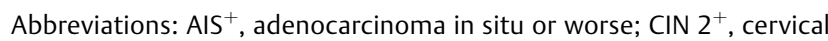
squamous intraepithelial neoplasia grade 2 or worse; $95 \% \mathrm{Cl}, 95 \%$ confidence interval; NPV, negative predictive value; PPV, positive predictive value.

findings. Conversely, a study that used ASC- $\mathrm{H}^{+}$as a cut-off point to ascertain the performance for the detection of CIN $2^{+}$reported SE of $67.9 \%$ and SP of $87 \% .^{30}$

In this study, SE of major or suspicious for invasion

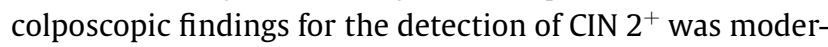
ate $(62 \%)$, while SP was low (59\%). Although these values were different from each other, this difference was not statistically significant, since their confidence interval overlapped. The major or suspicious for invasion colposcopic findings failed to identify a substantial number of patients with CIN $2^{+}$. Consequently, the absence of colposcopic images showing major or suspicious for invasion findings does not rule out a large number of healthy participants.

These results are in line with a previous study, ${ }^{3}$ and suggest that guided biopsies are needed by women with cytological abnormalities, even if they present subtle colposcopic findings, that is, those colposcopic images classified as minor findings by the IFCPC. Taking multiple biopsies would also be an acceptable strategy to improve the SE of colposcopy. ${ }^{31}$

The SE of major or suspicious for invasion colposcopic findings for the detection of $\mathrm{AIS}^{+}$was high (86\%), while the SP and PPV were low (59\% and 44\%, respectively). This high SE value found for the detection of $\mathrm{AIS}^{+}$implies that the major or suspicious for invasion colposcopic findings express low rates of false-negatives for this singular histopathological type of neoplasia. In view of these colposcopic images, whether squamous neoplasias are suspected or not, the need to exclude a possible coexistent glandular neoplasia still persists.

These results show that the SE values of colposcopic findings were higher for the detection of squamous (62\%) 


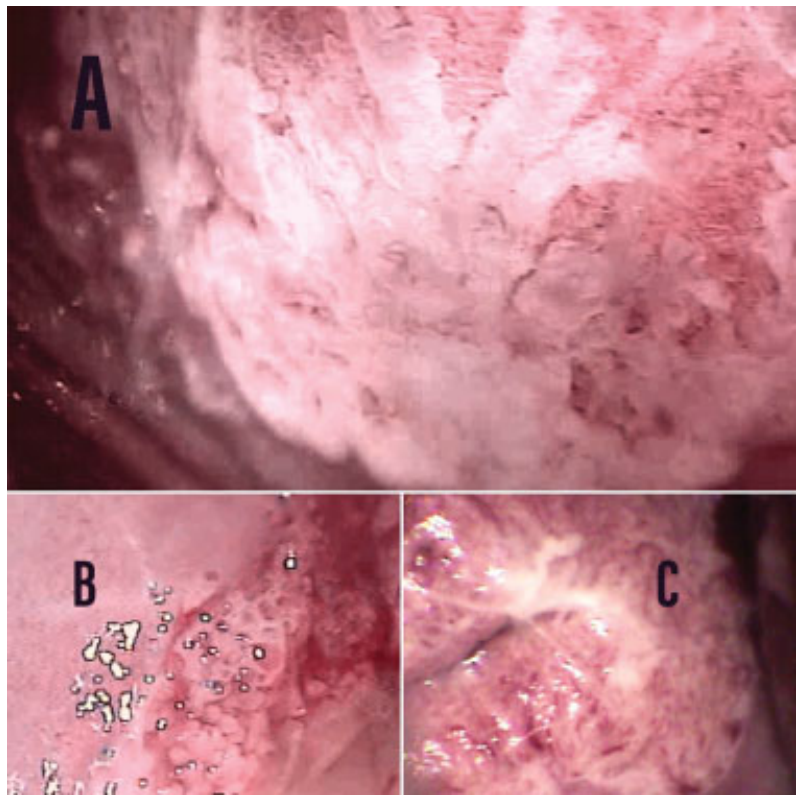

Fig. 1 New colposcopic images are herein named: (A) fused acetowhite villi with invaginated borders; (B) obstructed dilated grouped glands; (C) atypical vessels in cylindrical epithelium area.

and glandular (86\%) neoplasias than the cytological findings of $\mathrm{ASC}_{-} \mathrm{H}^{+}$(44\% and $72 \%$ for squamous and glandular neoplasias, respectively). However, SP values of ASC- $\mathrm{H}^{+}$(79\% and $79 \%$ ) were higher than those of colposcopic findings (59\% and $59 \%$ ) for the detection of these two main histopathological types of neoplasia. Moreover, the SE of major or suspicious for invasion colposcopic findings and $\mathrm{ASC}-\mathrm{H}^{+}$cytological findings were higher for glandular ( $86 \%$ and $72 \%$ ) than for squamous neoplasias (62\% and $44 \%$ ).

The high SE of colposcopy for the detection of glandular neoplasias found in this study was probably due to the inclusion of new subtle images in the major colposcopic finding category. Such new images are similar to those identified by Wright et $\mathrm{al}^{10}$ as suggestive of glandular neoplasias and are not described in the International Colposcopic Classification of the IFCPC. ${ }^{9}$ They are herein named: obstructed dilated grouped glands, fused acetowhite villi with invaginated borders, and atypical vessels in cylindrical epithelium area (-Fig. 1).

Considering that the PPV of ASC $-\mathrm{H}^{+}(88 \%)$ and major or suspicious for invasion colposcopic findings (85\%) for the detection of $\mathrm{CIN} 2^{+}$were high, the see and treat protocol, already endorsed by previous published evidences, ${ }^{32}$ is here corroborated as a secure option. The sequential use of two tests with high PPV prior to the see and treat protocol substantially decreases the probability of performing unnecessary excisional procedures in disease-free patients, mainly because both cytological and colposcopic findings must simultaneously be abnormal to indicate such management.

The possibility of finding an unexpected glandular neoplasia in a see and treat excision piece, estimated to happen in $52 \%$ of the patients with final diagnosis of $\mathrm{AIS}^{+}, 33$ would not contraindicate this approach. As a matter of fact, evidences have shown that outpatient excisional procedures are also suitable for the management of glandular neoplasias. ${ }^{33,34}$

\section{Conclusion}

The performance of cytological abnormalities is somehow different from that of colposcopic findings to predict the diagnoses of $\mathrm{AIS}^{+}$and $\mathrm{CIN}^{+}$. Sensitivity of major or suspicious for invasion colposcopic findings for the diagnoses of $\mathrm{CIN} 2^{+}$was moderate. The high PPV values found for ASC- ${ }^{+}$ and major or suspicious for invasion colposcopic findings for the detection of $\mathrm{CIN}^{+}$endorse the see and treat protocol. Sensitivity results of $\mathrm{ASC}_{-} \mathrm{H}^{+}$and major or suspicious for invasion were higher for the diagnosis of glandular than squamous neoplasias. These results reinforce the role of cytology in sorting out women at risk who should have their diagnosis settled by colposcopy and histopathology.

\section{Contributions}

Fachetti-Machado G., Figueiredo-Alves R. R. and Moreira M. A. R. contributed with the project and interpretation of data, writing of the article, critical review of the intellectual content and final approval of the version to be published.

\section{Conflicts of Interest}

The authors have no conflicts of interest to declare.

\section{References}

1 Koss LG. The Papanicolaou test for cervical cancer detection. A triumph and a tragedy. JAMA 1989;261(05):737-743. Doi:10. 1001/jama.1989.03420050087046

2 Chan PG, Sung HY, Sawaya GF. Changes in cervical cancer incidence after three decades of screening US women less than 30 years old. Obstet Gynecol 2003;102(04):765-773. Doi:10.1016/S0029-7844 (03)00696-3

3 Massad LS, Jeronimo J, Katki HA, Schiffman M; National Institutes of Health/American Society for Colposcopy and Cervical Pathology Research Group. The accuracy of colposcopic grading for detection of high-grade cervical intraepithelial neoplasia. J Low Genit Tract Dis 2009;13(03):137-144. Doi:10.1097/LGT.0b013e31819308d4

4 Jordan J, Arbyn M, Martin-Hirsch P, et al. European guidelines for quality assurance in cervical cancer screening: recommendations for clinical management of abnormal cervical cytology, part 1. Cytopathology 2008;19(06):342-354. Doi:10.1111/j.1365-2303.2008.00623.x

5 Drolet M, Bénard É, Boily MC, et al. Population-level impact and herd effects following human papillomavirus vaccination programmes: a systematic review and meta-analysis. Lancet Infect Dis 2015;15(05):565-580. Doi:10.1016/S1473-3099(14)71073-4

6 Jeronimo J, Schiffman M. Colposcopy at a crossroads. Am J Obstet Gynecol 2006;195(02):349-353. Doi:10.1016/j.ajog.2006.01.091

7 Nayar R, Wilbur DC. The Pap Test and Bethesda 2014. "The reports of my demise have been greatly exaggerated." (after a quotation from Mark Twain). Acta Cytol 2015;59(02):121-132. Doi:10.1159/0003 81842

8 Ministério da Saúde. Instituto Nacional de Câncer José Alencar Gomes da Silva. Coordenação de Prevenção e Vigilância. Divisão de Detecção Precoce e Apoio à Organização de Rede. Diretrizes Brasileiras para o Rastreamento do Câncer do Colo do Útero. 2a ed. Rio de Janeiro, RJ: INCA; 2016. http://www1.inca.gov.br/inca/ Arquivos/DDiretrizes_para_o_Rastreamento_do_cancer_do_colo _do_utero_2016_corrigido.pdf. Acessed March 26, 2018 
9 Bornstein J, Bentley J, Bösze P, et al. 2011 colposcopic terminology of the International Federation for Cervical Pathology and Colposcopy. Obstet Gynecol 2012;120(01):166-172. Doi:10.1097/AOG.0b013e 318254f90c

10 Wright VC, Dubuc-Lissoir J, Ehlen T, Heywood M, Plante M. Guidelines on adenocarcinoma in situ of the cervix: clinical features and review of management. J Obstet Gynaecol Can 1999;21(07):699-706. Doi:10.1016/S0849-5831(16)30106-9

11 Scully RE, Bonfiglio TA, Kurman RJ, Silverberg SG, Wilkinson EJ. Histological Typing of Female Genital Tract Tumors. 2nd ed. Berlin: Spring Verlag; 1994

12 Buckley $\mathrm{CH}$, Butler EB, Fox H. Cervical intraepithelial neoplasia. J Clin Pathol 1982;35(01):1-13. Doi:10.1136/jcp.35.1.1

13 Bonita R, Beaglehole R, Kjellström T. Epidemiologia Básica. 2a ed. São Paulo, SP: Santos; 2010

14 Kietpeerakool C, Srisomboon J, Prompittayarat W, Kanjanavaha P, Peuwsai R, Dheerakul C. Can adenocarcinoma in situ of the uterine cervix be predicted before cervical conization? Asian Pac J Cancer Prev 2006;7(04):522-524

15 Miller RA, Mody DR, Tams KC, Thrall MJ. Glandular lesions of the cervix in clinical practice: a cytology, histology, and human papillomavirus correlation study from 2 institutions. Arch Pathol Lab Med 2015;139(11):1431-1436. Doi:10.5858/arpa.2014-0633-OA

16 Patil PR, Jibhkate SN. Cytohistopathological correlation of Papanicolaou smears: a hospital based study. Int J Reprod Contracept Obstet Gynecol 2016;5:1695-1699. Doi:10.18203/2320-1770. ijrcog20161424

17 Naik R, Minj AM, Panda R, Satpathi S, Behera PK, Panda KM. Cytohistological correlation and accuracy of the Pap smear test in diagnosis of cervical lesions: a hospital based cross-sectional study from Odisha, India. Med Sci 2015;3:242-249. Doi:10.29387/ms.2015.3.3.242-249

18 Alves RRF, Teixeira TS, Netto JCA. Performance da citologia e colposcopia frente à histopatologia no rastreamento e diagnóstico das lesões precursoras do câncer do colo uterino. DST J Bras Doenças Sex Transm. 2002;14:33-38

19 Sankaranarayanan R, Thara S, Sharma A, et al; Multicentre Study Group on Cervical Cancer Early Detection in India. Accuracy of conventional cytology: results from a multicentre screening study in India. J Med Screen 2004;11(02):77-84. Doi:10.1258/ 096914104774061056

20 Wu Q Zhao X, Fu Y, et al. A cross-sectional study on HPV testing with type 16/18 genotyping for cervical cancer screening in 11,064 Chinese women. Cancer Med 2017;6(05):1091-1101. Doi:10.1002/cam4.1060

21 Bigras G, de Marval F. The probability for a Pap test to be abnormal is directly proportional to HPV viral load: results from a Swiss study comparing HPV testing and liquid-based cytology to detect cervical cancer precursors in 13,842 women. Br J Cancer 2005;93 (05):575-581. Doi:10.1038/sj.bjc.6602728

22 Cárdenas-Turanzas M, Nogueras-Gonzalez GM, Scheurer ME, et al. The performance of human papillomavirus high-risk DNA testing in the screening and diagnostic settings. Cancer Epidemiol Biomarkers Prev 2008;17(10):2865-2871. Doi:10.1158/1055-9965. EPI-08-0137

23 Yeoh GP, Chan KW. The accuracy of Papanicolaou smear predictions: cytohistological correlation of 283 cases. Hong Kong Med J 1997;3(04):373-376

24 Coste J, Cochand-Priollet B, de Cremoux P, et al; French Society of Clinical Cytology Study Group. Cross sectional study of conventional cervical smear, monolayer cytology, and human papillomavirus DNA testing for cervical cancer screening. BMJ 2003;326 (7392):733. Doi:10.1136/bmj.326.7392.733

25 Mayrand MH, Duarte-Franco E, Rodrigues I, et al; Canadian Cervical Cancer Screening Trial Study Group. Human papillomavirus DNA versus Papanicolaou screening tests for cervical cancer. $N$ Engl J Med 2007;357(16):1579-1588. Doi:10.1056/NEJMoa071430

26 Petry KU, Menton S, Menton M, et al. Inclusion of HPV testing in routine cervical cancer screening for women above 29 years in Germany: results for 8466 patients. Br J Cancer 2003;88(10): 1570-1577. Doi:10.1038/sj.bjc.6600918

27 Ronco G, Cuzick J, Pierotti P, et al. Accuracy of liquid based versus conventional cytology: overall results of new technologies for cervical cancer screening: randomised controlled trial. BMJ 2007; 335(7609):28. Doi:10.1136/bmj.39196.740995.BE

28 Moy LM, Zhao FH, Li LY, et al. Human papillomavirus testing and cervical cytology in primary screening for cervical cancer among women in rural China: comparison of sensitivity, specificity, and frequency of referral. Int J Cancer 2010;127(03):646-656. Doi:10.1002/ijc.25071

29 Arbyn M, Sankaranarayanan R, Muwonge R, et al. Pooled analysis of the accuracy of five cervical cancer screening tests assessed in eleven studies in Africa and India. Int J Cancer 2008;123(01): 153-160. Doi:10.1002/ijc.23489

$30 \mathrm{Kim} \mathrm{SH}$, Lee JM, Yun HG, et al. Overall accuracy of cervical cytology and clinicopathological significance of LSIL cells in ASC-H cytology. Cytopathology 2017;28(01):16-23. Doi:10.1111/cyt.12351

31 Underwood M, Arbyn M, Parry-Smith W, et al. Accuracy of colposcopy-directed punch biopsies: a systematic review and meta-analysis. BJOG 2012;119(11):1293-1301. Doi:10.1111/ j.1471-0528.2012.03444.x

32 Aue-Aungkul A, Punyawatanasin S, Natprathan A, Srisomboon J, Kietpeerakool C. "See and treat" approach is appropriate in women with high-grade lesions on either cervical cytology or colposcopy. Asian Pac J Cancer Prev 2011;12(07):1723-1726

33 Bryson P, Stulberg R, Shepherd L, McLelland K, Jeffrey J. Is electrosurgical loop excision with negative margins sufficient treatment for cervical ACIS? Gynecol Oncol 2004;93(02): 465-468. Doi:10.1016/j.ygyno.2004.01.028

34 Jiang Y, Chen C, Li L. Comparison of cold-knife conization versus loop electrosurgical excision for cervical adenocarcinoma in situ (ACIS): a systematic review and meta-analysis. PLoS One 2017;12 (01):e0170587. Doi:10.1371/journal.pone.0170587 